Impact Factor: 4.845(SJIF) Research Journal Of English (RJOE) Vol-5, Issue-1, 2020

www.rjoe.org.in An International Peer-Reviewed English Journal

ISSN: 2456-2696

Indexed in: International Citation Indexing (ICI), International Scientific Indexing

(ISI), Directory of Research Journal Indexing (DRJI) Google Scholar \& Cosmos.

\title{
POST INDEPENDENCE SOCIO-POLITICAL REALITIES IN NGUGI WA THIONGO'S PETALS OF BLOOD
}

\author{
Dr. K. V. Ramana Chary ${ }^{1}$ \\ Head, Department of English \\ Telangana University, Dichpally - Nizamabad - 503322 -TS \\ Mr. M. Venumadhav ${ }^{2}$ \\ Research Scholar, Dept. of English, Telangana Univrsity - Dichpally - Nizamabad - TS
}

The ultimate tragedy is not the oppression and cruelty by the bad people but the silence over that by the good people

- Martin Luther King, Jr.

\begin{abstract}
Ngugi wa Thiong'o, the Kenyan novelist, critic and playwright, has drawn worldwide critical attention for his mastery of medium of fiction as well as his activist writings. His large corpus of work carries the stamp of the strong impetus of activist in him and his overtly ideological position has only added a thrust to his fictional works. Ngugi has written both during the colonial and post-colonial periods and as such his works portray different periods in recent Kenyan history--its independence struggle, Mau Mau rebellion which is a recurrent motif in his novels, and the resistance to neo-colonial policies and attitudes in the form of postindependence disillusion evident since his fourth novel Petals of Blood. History and politics thus play a major part in Ngugi's fiction. His literary consciousness is shaped by liberation aesthetics or poetics of commitment. The present paper makes an attempt to unfold the post independent socio-political realities in Kenyan societies.
\end{abstract}

In Petals of Blood, Ngugi attempts to survey the unpleasant events of neocolonial scenario of the country between 1963 and 1975. As the title implies the new world manifests in the flowering (Petals) of a new egalitarian and just order brought about by struggle and sacrifice (blood). The thematic strands depicted in the novel are politics, colonial and neocolonial, history past and present, its impact, violence and its manifold nature. This artistic representation of betrayal of independence movement is perhaps the most authentic account of the evils perpetrated in independent African society by the neo-colonial masters who represent the interests of western capitalists. In this novel Ngugi depicts the nexus between the above vile forces by illuminating the economic structure and class formations, conflicts and contradictions, and political and cultural struggles in contemporary Kenya. The politics associated with land is central to the complex thematic pattern of Petals of Blood. Ngugi shows how the imperial colonists alienated Africans from their land and later how African landlords occupied 
Impact Factor: 4.845(SJIF) Research Journal Of English (RJOE) Vol-5, Issue-1, 2020

www.rjoe.org.in An International Peer-Reviewed English Journal

ISSN: 2456-2696

Indexed in: International Citation Indexing (ICI), International Scientific Indexing (ISI), Directory of Research Journal Indexing (DRJI) Google Scholar \& Cosmos.

the same and exploited the poor.

Key words: neo-colonial policies - imperial colonists - independence movement - liberation - commitment

Ngugi wa Thiong'o, the Kenyan novelist, critic and playwright, has drawn worldwide critical attention for his mastery of medium of fiction as well as his activist writings. His large corpus of work carries the stamp of the strong impetus of activist in him and his overtly ideological position has only added a thrust to his fictional works. Ngugi has written both during the colonial and post-colonial periods and as such his works portray different periods in recent Kenyan history--its independence struggle, Mau Mau rebellion which is a recurrent motif in his novels, and the resistance to neo-colonial policies and attitudes in the form of post-independence disillusion evident since his fourth novel Petals of Blood. History and politics thus play a major part in Ngugi's fiction. His literary consciousness is shaped by liberation aesthetics or poetics of commitment. The present paper makes an attempt to unfold the post independent socio-political realities in Kenyan societies.

Ngugi wa Thiong'o was born at Kamarithu, Limuru in Kenya on January 5, 1938. He completed his primary education in two schools, one run by the Church of Scotland, and the other at Maangum Karing'a School in neighbourhood, which was renamed Kinyogoori Primary School. After attending a missionary school, Alliance High School, Kikuyu during 1954-58, Ngugi joined Makerere University College, Kampala, Uganda in 1959 from which he graduated in 1964. After his studies at the University of Leeds from 1964 to 1967, Ngugi returned to Africa and served as Lecturer in English at Universtiy College, Nairobi in 1968. He offered his resignation for lectureship in protest against government interference with academic freedom in the university. After a short spell of lecturership at Northwestern University in U.S.A. during 1970-71, Ngugi returned to University of Nairobi as lecturer in 1971 and became Acting Chairman in the Dept of Literature in 1973 and became Associate Professor in 1976. He was called James Ngugi until March 1970 and later he adopted the new traditional Kikuyu name, Ngugi wa Thiong'o. Regarding introduction of the colonial education in the missionary schools, Ngugi says:

You must see universities in Africa in their colonialist missionary setting. They didn't want you to question things, or compare western institutions with other systems. One or two of the lecturers were enlightened, but they nearly all believed that the only real education was to be found in Britain. Literature has nothing or very little to do with what was happening in Africa. So, in the novels and plays we learned about British people. And even then we learned about them not in terms of social issues, but in terms of universal values and 
Impact Factor: 4.845(SJIF) Research Journal Of English (RJOE) Vol-5, Issue-1, 2020

www.rjoe.org.in An International Peer-Reviewed English Journal

ISSN: 2456-2696

Indexed in: International Citation Indexing (ICI), International Scientific Indexing (ISI), Directory of Research Journal Indexing (DRJI) Google Scholar \& Cosmos.

the tragedy of a human being caught in a situation whose conditions he cannot control (Decolonizing the Mind, 2).

Ngugi's work explains the political aspects of colonial and neo colonial experience. As one who has deep commitment to the African values his writings expose the many evils that plagued the post-independent African societies such as corruption, hypocrisy, sexual exploitation of women, oppression and violence - all a fallout from colonial experience. The first two novels of Ngugi, Weep Not, Child and The River Between are good examples of reflection of African culture, history and tradition. Besides, the colonial experience dominates in these novels. A Grain of Wheat is a celebration of the Mau Mau rebellion as well as a condemnation of its betrayers. Petals of Blood is a significant turning point in the growth of the novelist and projection of his concerns. The multiple points of view which he experimented in A Grain of Wheat is sought to be perfected in Petals of Blood. Thematically and structurally it is the connecting point between his earlier English novels and the subsequent novels written in Gikuyu. Ngugi followed the practice of writing in English for a period and then changed his position from his fifth novel, Devil on the Cross onwards and says, "I would attempt a novel in the very language which had been the basis of incarceration. I would reconnect myself not to the Afro-European novels of my previous practice but to the African novel of my new commitment" (Decolonizing the Mind, 71).

The post independence political situation in Kenya has been marked by corruption and nepotism. It has been described as most undemocratic and oppressive. The single party multi-candidate constituency system is used by the ruling party, KANU to hoodwink the masses into believing they have real democracy, whereas in practice coercion is used to deny even minimum symptoms of democracy. Whoever has economic power and a tribal backing can become KANU leader whether he has ever been a worker of the party or not. As a matter of fact there are no activist members; there are only leaders and their gang of ruffians. Vijay Gupta makes the following observations in respect of the political situation in Kenya after independence:

In Kenya the bureaucratic bourgeoisie played the tune of ruling circles and abetted them in enriching the latter and impoverishing the masses. In the process every politician used state power to extend his political base. He tried to help his supporters by providing jobs in government and semigovernmental agencies. The family members of politicians were placed in jobs of prestige and power and were given contracts, licenses for business, manufacturing and agricultural activities. All such politicians acquired land in rural and urban areas through corrupt methods and beyond their means. Jomo Kenyatta, the president of Kenya, whose family acquired wealth beyond all proportions, is the best example of the misuse of power. His daughter, son, 
Impact Factor: 4.845(SJIF) Research Journal Of English (RJOE) Vol-5, Issue-1, 2020

www.rjoe.org.in An International Peer-Reviewed English Journal

ISSN: 2456-2696

Indexed in: International Citation Indexing (ICI), International Scientific Indexing (ISI), Directory of Research Journal Indexing (DRJI) Google Scholar \& Cosmos.

son-in-law, cousin etc., all formed a powerful economic group and a political caucus (Kenya: Politics of (In) Dependence, 200).

The post-independence political situation in Kenya as in any African country offered a green and murky scenario wherein the ruling class and its acolytes were the only beneficiaries of freedom. It was a negation of people's dreams and aspirations, Ngugi was in the forefront of portraying this disillusionment and as such he earned the wrath of the ruling sections, first of Kenyatta and then of Moi regime. Ngugi's Petals of Blood is a documentation of distressed events during the Mau Mau struggle for liberation. It also depicts the neo-colonial situation of Kenya. Petals of Blood opens with the news that three leading Kenyans have been murdered. The search for the guilty is undertaken by Inspector Godfrey. As the novel unfolds the motives that each has for the killings are revealed and also related to the underlying thematic concerns of power, wealth and corruption.

In Petals of Blood, Ngugi attempts to survey the unpleasant events of neocolonial scenario of the country between 1963 and 1975. As the title implies the new world manifests in the flowering (Petals) of a new egalitarian and just order brought about by struggle and sacrifice (blood). The thematic strands depicted in the novel are politics, colonial and neocolonial, history past and present, its impact, violence and its manifold nature. This artistic representation of betrayal of independence movement is perhaps the most authentic account of the evils perpetrated in independent African society by the neo-colonial masters who represent the interests of western capitalists. In this novel Ngugi depicts the nexus between the above vile forces by illuminating the economic structure and class formations, conflicts and contradictions, and political and cultural struggles in contemporary Kenya. The politics associated with land is central to the complex thematic pattern of Petals of Blood. Ngugi shows how the imperial colonists alienated Africans from their land and later how African landlords occupied the same and exploited the poor. Eustace Palmer says that of all the African novels, Petals of Blood "presents the most comprehensive analysis to date of the evils perpetrated in Independent African society by black imperialists and capitalists" (The Growth of African Novel, 228).

In Petals of Blood Ngugi analyses the class antagonism between the capitalists and the working class. As Simon Gikandi puts it, "Political idea and ideology are not merely aspects of local color but function as determinates of form and content" (Reading the African Novel, 114). Ngugi's novel presents the psychological, sociological and political factors involved in the working class people's struggle for equitable share in land, property and power. The novel, as such, portrays several characters from all sections of Kenyan society. 
Impact Factor: 4.845(SJIF) Research Journal Of English (RJOE) Vol-5, Issue-1, 2020

www.rjoe.org.in An International Peer-Reviewed English Journal

ISSN: 2456-2696

Indexed in: International Citation Indexing (ICI), International Scientific Indexing (ISI), Directory of Research Journal Indexing (DRJI) Google Scholar \& Cosmos.

The novel opens with an investigation. Chief inspector Godfrey of the Kenyan police force conducts an investigation into the murder of three men-Kimeria, Chui and Mzigo. Each is a businessman with investments in New Ilmorog. The three men have been murdered in Wanja's hostelry and their bodies burnt in a fire. The main suspects are Munira, Abdulla, Wanja and Karega. The first suspect is Munira. He is the village school master. His life has been characterized by an unsuccessful search for the means to overcome his failure. The second of the suspects is Abdulla, the son of an African mother and Indian father. He was a freedom fighter earlier. In the independence war he had lost a leg. He does not receive the rewards of the independence and travels to Ilmorog to sell drinks to peasants.

Wanja, the third suspect, comes to Ilmorog to live with her grand mother. When she was a school girl, she was seduced by a married man who abandoned her when she became pregnant. She threw her new born child down a drain. She works as a barmaid in Abdulla's shop. Karega is the fourth suspect who hails from Limuru. He became a teacher in Munira's school. Munira is jealous of the love between Wanja and Karega. Munira becomes a drunkard and Wanja becomes the prosperous madam of Ilmorog.

Wanja is central to Ngugi's development of his theme of social disintegration. Her portrayal shows the causes of prostitution in modern African societies. Seduced at an early age by an irresponsible married man old enough to be her father she becomes pregnant and leaves home and school unable to bear the taunts and cruelty of her parents. In desperation, she kills her baby and ventures out into the big city, on the mercies of even more unscrupulous men determined to exploit and degrade her. She finds it tough to survive in the concrete jungle of the town. After her regeneration in Ilmorog, when she discovers a new sense of purpose in helping to engineer the society's revival, she is thrown back into highclass prostitution through the intrigues of the new, native capitalists. Wanja is creative and imaginative, but she is also a practical woman who understands that in order to survive in the given conditions one must use all weapons and that mere idealism will not help.

Besides focusing on power, patriotic struggle, liberation and rebellion, the present study is an analysis of Ngugi's commitment and his socio-political analysis of the Kenyan society and his deep commitment to the African values. His writings mirror the factual human plight and dreadful human situations in Kenya. He makes an attempt to achieve pride, dignity and equality to African people. Ngugi's Marxist and revolutionary ideology is very clearly reflected in his novels.

\section{Reference:}

- Wa Thiango, Ngugi. Decolonizing the Mind: The Politics of Language in African Literature. London: James Curry, 1986. 
Impact Factor: 4.845(SJIF) Research Journal Of English (RJOE) Vol-5, Issue-1, 2020

www.rioe.org.in An International Peer-Reviewed English Journal ISSN: 2456-2696

Indexed in: International Citation Indexing (ICI), International Scientific Indexing (ISI), Directory of Research Journal Indexing (DRJI) Google Scholar \& Cosmos.

- Gupta, Vijay. Kenya: Politics of (In) Dependence. New Delhi: People's Publishing House, 1981.

- Palmer, Eustace. The Growth of the African Novel. London: Heinemann, 1979.

- Gikandi, Simon. Reading the African Novel. London: James Curry, 1987. 